\title{
Chlorophyll index (SPAD) and macronutrients relation and productive performance of sorghum hybrids in different sowing dates
}

\author{
César Henrique Souza Zandonadi*1, Carlos Juliano Brant Albuquerque², Rogério Soares de Freitas ${ }^{3}$ \\ ${ }^{1}$ Federal University of Uberlândia/UFU, Institute of Agricultural Science, Campus Umuarama Block 2E, \\ Uberlândia, MG, Brazil \\ ${ }^{2}$ Minas Gerais State Agricultural Research Corporationa/EPAMIG, Uberlândia, MG, Brazil \\ 3Paulista Agency of Agriculture Technology (APTA), Votuporanga, SP, Brazil
}

*Corresponding author: cesarzandonadi@yahoo.com.br

\begin{abstract}
Sorghum is a crop already established for off season planting, in succession to soybeans in the Southeast, Midwest and also in some areas of Northeast in Brazil. Studying new cultivars is necessary for the sorghum development in the country. Therefore, this study evaluated the productive performance of sorghum in different sowing dates and determined the SPAD chlorophyll index, correlating it with macronutrient contents in hybrids in different development stages and sowing dates. Experiments were conducted in contiguous areas in four sowing dates, the first one was sown on February 262013 and the others at 17, 30 and 41 days after the first sowing - (DAFS). The experiments were conducted in a randomized block design with nine hybrids and four replications. Each sowing date was considered an individual experiment, and grouped analysis was done to compare characteristics. Macronutrients and indexes content data of Soil Plant Analytical Division value (SPAD) were evaluated at three different stages within the plant cycle, characterizing an experiment in split plot (development stages - subplots), with the factor in the plot (hybrid x sowing time). Pearson's correlation coefficients for the variables macronutrient and SPAD index were calculated. Production performance of sorghum hybrids varied according to sowing dates. Macronutrient content of sorghum hybrids varied in different development stages evaluated and sowing dates. SPAD chlorophyll index values have positive linear correlations with nitrogen content in the analyzed phenological stages.
\end{abstract}

Keywords: Chlorophyll; Mineral nutrition; Nutrient extraction; Sorghum bicolor L.; SPAD-502 Minolta.

Abbreviations: Ca- calcium; DAFS- days after first sowing; K- potassium; Mg- magnesium; N- nitrogen; P- phosphorus; SPADsoil plant analytical value; $\mathrm{S}$ - sulfur.

\section{Introduction}

Sorghum is a C4 metabolism plant, which highlights great tolerance to climatic weather with high grain production, especially in dry and hot climate regions. These characteristics contribute to the expansion of cultivation in the same area in Brazil, especially in areas with low rainfall and high temperatures. The sorghum plant has various types of utility, emphasizing the use of grain and fodder for animal feed (Fernandes et al., 2014; Barbero et al., 2014; Rodrigues et al., 2014), power generation, biofuels (May et al., 2014) among others. Their cultivation is also associated with replacing corn as an energy supply, when growing conditions and corn prices are not favorable (Moreira et al., 2014). The grain sorghum came to Brazil probably by Northeast, from African slaves during the colonial period. Currently, sorghum is the fifth most planted cereal in the world after wheat, rice, corn and barley, considering for almost $85 \%$ of all energy consumed by man (Ribas, 2014; Borghi et al., 2014). Production of sorghum in Brazil has increased both by expanding its area of cultivation, as well as increasing productivity. In the season of 2012/2013 it was estimated a planted area of 836,400 hectares, $6.3 \%$ growth over the previous harvest. The states with the largest cultivated area are Goiás, Minas Gerais and Mato Grosso, respectively (Conab, 2014). Even so the culture has easy adaptation of its cultivars for different soil fertility conditions, tolerance to high temperature and water stress (Miranda et al., 2010; Franco, 2011). Some of these existing cultivars on the market have differences in their grain yield, vegetative cycle and height of plants (Borghi et al., 2013). These different productivity directly reflect the amount of nutrients extracted and exported by culture, therefore the extremely importance to understand this information to set the appropriate management of soil fertility and plant nutrition in order to the fully exploitation of the culture's productive potential (Santos et al., 2014; Bull et al., 1993). Knowing the amount of nutrients that the plant demands, it should be noted the nutritional status of the plant during the development to prevent any deficiency that would lead to productivity reduction. However today, the techniques used to assess the nutritional status of plants spend a lot of time, are laborious and expensive. Therefore, the use of fast accurate technical assessment of the nutritional status of plants is interesting for the producer. One such tool is the chlorophyll meter. This device makes quick and simple measurements form of chlorophyll content in plant leaves, which may be related to its nutrient content (Magalhães et al., 2009; Rocha et al., 2005; Zotarelli et al., 2003; Argenta et al., 2001). The sowing date is a factor that directly influences the growth and 
development of plants and their recommendation is mainly based on prevailing edaphoclimatics conditions (Lima, et al., 2010; Sans et al., 2003). The grain sorghum is cultivated mainly in the off-season, and this time is characterized by great water limitation and the efficiency of fertilizers is reduced by the lack of water. The use of cultivars adapted to these production systems and environmental conditions of farming region are important factors to contribute to the maximization of traits of agronomic interest. Thus, the objectives of this study were to evaluate the agronomic characteristics and macronutrient contents of sorghum hybrids in different sowing dates and to relate the SPAD index obtained by chlorophyll with the macronutrient in plants in different development stages.

\section{Results and Discussion}

\section{Plant Height (cm)}

Related to the height $(\mathrm{cm})$, it can be noticed that all the hybrids showed higher average height when sown on 26/02. When sowing took place at 17 DAFS most had lower average height, except for the EXP001 hybrids, 1G220 and BUSTER that showed average time that didn't differ statistically when seeding were conducted at 30 and 41 DAFS (Table 3). In the first sowing date (0 DAFS) hybrid 1G282 was higher and at 17 DAFS this hybrid with EXP001, 50A10 and BUSTER were the highest (Table 3). When sowing occurred at 30 and 41 DAFS the largest hybrid was 1G282, differing from the other hybrids. The average height in the experiment ranged between 54.75 and $124.75 \mathrm{~cm}$. Experiments such as Hecker (2002), Silva et al. (2009) and Almeida Filho et al. (2014) evaluated the agronomic characteristics of various grain sorghum hybrids during the period between harvests, among them the height $(\mathrm{cm})$. Hecker (2002) found average values ranging $95-166 \mathrm{~cm}$. Silva et al. (2009) found values between 100 and $150 \mathrm{~cm}$, similar results to those found by Almeida Filho et al. (2014), that among the hybrids, the $1 \mathrm{G} 282$ showed the highest average height. The height values $(\mathrm{cm})$ of these experiments were relatively higher than those found in this experiment (Table 3). In the cited studies, the height of the plant was calculated from the base to the tip of the panicle, otherwise the present study the plant height was calculated from the base to the base of the panicle. Thus, the results were disparate to those found in the literature.

\section{Flowering (days)}

Regarding the flowering (days), in general, all hybrids except the hybrid BUSTER were more independent of late sowing. The 1G244 hybrids, EXP001, 1G100, 50A50 and 50A10 flourished in less time when the sowing of the same occurred after 41 DAFS and more time at 17 DAFS. The hybrid 1G282, BUSTER flourished faster on the 0 DAFS (Table 4). The average flowering (days) ranged between 51 and 68 . Similar results to these were obtained by Almeida Filho et al. (2014) evaluated the flowering hybrid when planted between the months of February and March, which had 51 days cycle, already sown on 15 April showed 70 days of flowering. Silva et al. (2009) obtained 80 days on average for the flowering of hybrids and sowing those held in March. Hecker (2002) obtained flowering between 62 and 79 days to several seeded hybrids in Mato Grosso do Sul off-season.

As shown in Figure 1, when sowing occurred at 17 DAFS $(15 / 03)$ there was a period of low water availability, and the cumulative ten-day period in this sowing was no more than $20 \mathrm{~mm}$ and with high average temperatures around $27.5^{\circ} \mathrm{C}$.
Furthermore, there was a 30 days dry periods between periods 7 and 9 (Figure 1), which mainly affect the hybrids were grown at 17,30 and 41 DAFS. These factors have caused the increase in the cycle and thus reducing the size of sorghum hybrids in response to this stress, as already demonstrated by Tolk et al. (2013) and Vanderlip (1993). The availability of hybrids from different cycles becomes a key strategy for the development of culture in times of climate instability. At the earliest sowings it is recommended longer cycle cultivars to spend most of the growing season, accumulating assimilates to reproductive age and maturity and the earliest cultivars in later sowings, enabling a shorter period of possible bad weather influences.

\section{Grain yield $\left(\mathrm{Kg} \mathrm{ha}^{-1}\right)$}

For productivity $\left(\mathrm{Kg} \mathrm{ha}^{-1}\right)$, the hybrids $1 \mathrm{G} 282$, 50A70 and 50A10 showed no significant differences between sowing dates (Table 5). The hybrids 1G244, 1G220 and 50A50 had lower productivities at 17 DAFS. The EXP001 and 1G100 hybrids when sown at 0 and 17 DAFS had lower productivity compared to other sowing dates. The hybrid BUSTER showed lower productivity when sown in the last three seasons (Table 5). Most hybrids had lower productivities at 17 DAFS. As discussed earlier, the flowering of plants when sown at 17 DAFS was later. This cycle elongation is related to drought stress period, which justifies lower yields for most hybrids in this period. Analyzing the productivity of hybrids within each time, it was noted that the first time (0 DAFS) hybrid BUSTER was superior to the others. At 17 DAFS was no difference between hybrids. Hybrid 1G100, EXP001, $50 \mathrm{~A} 50$ and $1 \mathrm{G} 282$ were the most productive at 30 DAFS. In the last season (41 DAFS) the 1G244 hybrids, EXP001, 1G100, 50A50, 1G282 and $1 \mathrm{G} 220$ performed better. Productivity averages ranged from 2902.08 to $6186.10 \mathrm{~kg}$ ha ${ }^{1}$, reaching the overall average of the experiment $4503.00 \mathrm{~kg}$ ha $^{-1}$. Silva et al. (2013) evaluating grain sorghum hybrids sown in summer 2010 obtained average yields around $5150.00 \mathrm{~kg} \mathrm{ha}^{-1}$, showing that the culture of productivity in the off season may be similar to the plantations made at the time of season, where environmental stress conditions are smaller. Almeida Filho et al. (2014) had average productivity around $3822.16 \mathrm{~kg} \mathrm{ha}^{-1}$, and the hybrid 1G282 was the most productive among the evaluated for him. Almeida Filho et al. (2010) also obtained similar yields, assessing 25 hybrids of sorghum, 20 experimental and 5 commercial, including the hybrid $1 \mathrm{G} 220$, which showed intermediate productivity. The sowing of hybrid was held in the first fortnight of March and the average ranged from 2800.00 to $5009.00 \mathrm{~kg} \mathrm{ha}^{-1}$. In the work of Silva et al. (2009) the yields were lower than those found in this work, ranging from 2267.00 to $3245.00 \mathrm{~kg} \mathrm{ha}^{-1}$ with the sowing in $05 / 03$ in Goiás Southwest region. The variation of sowing dates for grain sorghum production has direct influence on plant height and mainly in productivity. The later sowings, in general, has lower productivity mainly because of the increasing possibility of drought in these times (Borghi et al., 2013; Marin et al., 2006; Baumhardt et al., 2006; Lazzaroto, 2003).

\section{Evaluation of macronutrient content $\left(\mathrm{g} \mathrm{K \textrm {K } ^ { - 1 }}\right)$ in different sowing dates and different stadiums}

According to the results in Table 6, the amounts of all macronutrients are evaluated within the reference values for the sorghum culture, silking, available for interpretation tables and soil fertility manuals (Ribeiro et al., 1999; Cantarella et al., 1997). 
Table 1. Chemical attributes of the soil in the profile 0-0.2 m, Votuporanga, 2013.

\begin{tabular}{|c|c|c|c|c|c|c|c|c|c|c|c|c|c|}
\hline Layer & $\mathrm{pH} \mathrm{H}_{2} \mathrm{O}$ & $\mathrm{P}$ & $\mathrm{K}$ & $\mathrm{Al}$ & $\mathrm{Ca}$ & $\mathrm{Mg}$ & $\mathrm{H}+\mathrm{Al}$ & SB & $\mathrm{t}$ & $\mathrm{T}$ & V & $\mathrm{m}$ & $\mathrm{MO}$ \\
\hline & $(1: 2.5)$ & \multicolumn{2}{|c|}{$\mathrm{mg} \mathrm{dm}^{-3}$} & & 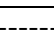 & --- & molcdm & & & & $\%$ & & dag $\mathrm{kg}^{-1}$ \\
\hline $0-0.2$ & 5.2 & 30 & 20 & 0 & 17 & 8 & 16 & 25.05 & 25.05 & 41.05 & 61 & 0 & 13 \\
\hline
\end{tabular}

$\mathrm{P}, \mathrm{K}=\left(\mathrm{HCl} 0.05 \mathrm{~mol} \mathrm{~L}^{-1}+\mathrm{H}_{2} \mathrm{SO}_{4} 0.0125 \mathrm{~mol} \mathrm{~L}^{-1}\right) \mathrm{P}$ available (extractor Mehlich-1); Ca, $\mathrm{Mg}, \mathrm{Al},(\mathrm{KCl} 1 \mathrm{~mol} \mathrm{~L}-1) ; \mathrm{H}+\mathrm{Al}=(\mathrm{Tampon}$ solution - $\mathrm{SMP}$ at pH 7.5$) ; \mathrm{SB}=$ Sum of basis; $\mathrm{t}=$ cation-exchange capacity $(\mathrm{CEC})$ effective; $\mathrm{T}=\mathrm{CEC}$ in $\mathrm{pH} 7.0 ; \mathrm{V}=$ Saturation for basis; $\mathrm{m}=$ Saturation for aluminum $(\mathrm{EMBRAPA}, 2009)$.

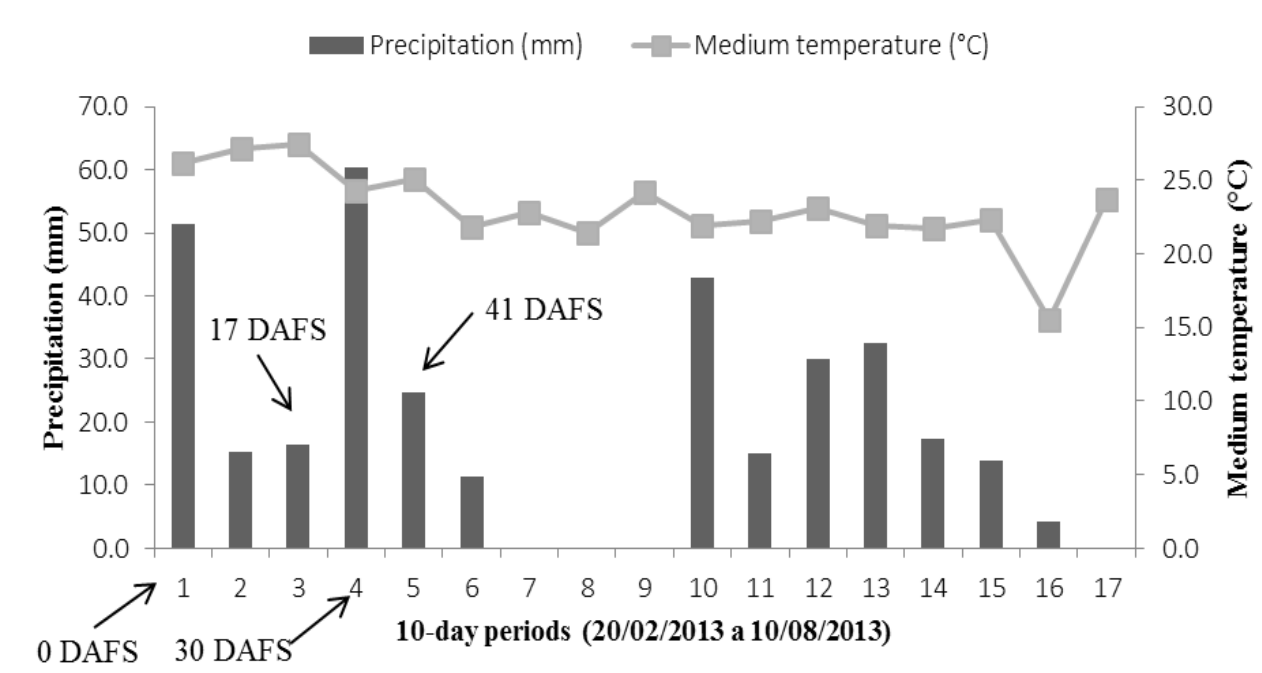

Fig 1. Variation in medium temperature $\left({ }^{\circ} \mathrm{C}\right)$ and accumulated precipitation (mm) for 10-day periods from February to August 2013 in Votuporanga, SP.

Table 2. Dates of sowing, emergence and coverage fertilization for the different sowings.

\begin{tabular}{lcccc}
\hline Date & Sowing & $\begin{array}{c}\text { Days after the first } \\
\text { sowing (DAFS) }\end{array}$ & Emergence & Coverage fertilizaton \\
\hline 1 & $26 / 02 / 2013$ & 0 & $02 / 03 / 2013$ & $20 / 03 / 2013$ \\
2 & $15 / 03 / 2013$ & 17 & $20 / 03 / 2013$ & $09 / 04 / 2013$ \\
3 & $28 / 03 / 2013$ & 30 & $01 / 04 / 2013$ & $18 / 04 / 2013$ \\
4 & $08 / 04 / 2013$ & 41 & $12 / 04 / 2013$ & $30 / 04 / 2013$ \\
\hline
\end{tabular}

Table 3. Height $(\mathrm{cm})$ of nine grain sorghum hybrids from four different sowing dates.

\begin{tabular}{lcccc}
\hline \multirow{2}{*}{ Hybrids } & \multicolumn{3}{c}{ Dates } \\
\cline { 2 - 5 } & 0 DAFS & 17 DAFS & $30 \mathrm{DAFS}$ & 41 DAFS \\
\hline 1G244 & $83.75 \mathrm{cA}$ & $57.50 \mathrm{bC}$ & $64.75 \mathrm{cB}$ & $67.75 \mathrm{bB}$ \\
EXP001 & $91.75 \mathrm{bA}$ & $66.00 \mathrm{aB}$ & $72.00 \mathrm{bB}$ & $66.50 \mathrm{bB}$ \\
1 G100 & $83.25 \mathrm{cA}$ & $56.25 \mathrm{bC}$ & $63.25 \mathrm{cB}$ & $65.50 \mathrm{bB}$ \\
50 A50 & $86.50 \mathrm{cA}$ & $57.00 \mathrm{bC}$ & $71.50 \mathrm{bB}$ & $67.25 \mathrm{bB}$ \\
$1 \mathrm{G} 282$ & $124.75 \mathrm{aA}$ & $67.75 \mathrm{aC}$ & $84.75 \mathrm{aB}$ & $87.50 \mathrm{aB}$ \\
$50 \mathrm{~A} 70$ & $79.50 \mathrm{cA}$ & $54.75 \mathrm{bC}$ & $66.00 \mathrm{cB}$ & $69.00 \mathrm{bB}$ \\
$1 \mathrm{G} 220$ & $79.00 \mathrm{cA}$ & $54.75 \mathrm{bB}$ & $62.25 \mathrm{cB}$ & $56.75 \mathrm{cB}$ \\
$50 A 10$ & $97.50 \mathrm{bA}$ & $61.00 \mathrm{aC}$ & $76.00 \mathrm{bB}$ & $68.25 \mathrm{bC}$ \\
BUSTER & $95.00 \mathrm{bA}$ & $62.25 \mathrm{aB}$ & $63.25 \mathrm{cB}$ & $66.75 \mathrm{bB}$ \\
\hline Uppercase letters in same row and lowercase letters in same column indicate differences according to the Scott-Knott test at a 0.05 level of significance.
\end{tabular}

Table 4. Flowering (days) of nine grain sorghum hybrids from four different sowing dates.

\begin{tabular}{lllll}
\hline \multirow{2}{*}{ Hybrids } & \multicolumn{3}{c}{ Dates } \\
\cline { 2 - 5 } & 0 DAFS & 17 DAFS & $30 \mathrm{DAFS}$ & 41 DAFS \\
\hline EX244 & $62.00 \mathrm{bC}$ & $67.00 \mathrm{aA}$ & $63.00 \mathrm{aB}$ & $58.00 \mathrm{cD}$ \\
$1 \mathrm{GP} 100$ & $58.25 \mathrm{eC}$ & $63.00 \mathrm{dA}$ & $61.00 \mathrm{cB}$ & $58.00 \mathrm{cC}$ \\
$50 \mathrm{~A} 50$ & $57.25 \mathrm{fB}$ & $63.75 \mathrm{cA}$ & $57.25 \mathrm{~dB}$ & $56.00 \mathrm{dC}$ \\
$1 \mathrm{G} 282$ & $62.00 \mathrm{bB}$ & $66.75 \mathrm{aA}$ & $62.25 \mathrm{bB}$ & $58.00 \mathrm{cC}$ \\
$50 \mathrm{~A} 70$ & $59.50 \mathrm{cD}$ & $66.75 \mathrm{aA}$ & $62.25 \mathrm{bB}$ & $60.75 \mathrm{bC}$ \\
$1 \mathrm{G} 220$ & $62.75 \mathrm{aB}$ & $65.75 \mathrm{bA}$ & $63.00 \mathrm{aB}$ & $63.00 \mathrm{aB}$ \\
$50 A 10$ & $62.00 \mathrm{bB}$ & $66.25 \mathrm{bA}$ & $62.00 \mathrm{bB}$ & $56.25 \mathrm{dC}$ \\
BUSTER & $58.75 \mathrm{dC}$ & $64.00 \mathrm{cA}$ & $63.00 \mathrm{aB}$ & $58.25 \mathrm{cC}$ \\
Uppercase letters in same row and lowercase letters in same column indicate differences according to the Scott-Knott test at a 0.05 level of significance.
\end{tabular}


Table 5. Productivity $\left(\mathrm{Kg} \mathrm{ha}^{-1}\right)$ of nine grain sorghum hybrids from four different sowing dates.

\begin{tabular}{|c|c|c|c|c|}
\hline \multirow{2}{*}{ Hybrids } & \multicolumn{4}{|l|}{ Dates } \\
\hline & 0 DAFS & 17 DAFS & 30 DAFS & 41 DAFS \\
\hline $1 \mathrm{G} 244$ & $4458.58 \mathrm{bA}$ & $2902.08 \mathrm{aB}$ & $4574.15 \mathrm{bA}$ & $4849.96 \mathrm{aA}$ \\
\hline EXP001 & $4094.38 \mathrm{bB}$ & $4286.45 \mathrm{aB}$ & $5338.78 \mathrm{aA}$ & $5345.25 \mathrm{aA}$ \\
\hline $1 \mathrm{G} 100$ & $4486.97 \mathrm{bB}$ & $3823.27 \mathrm{aB}$ & $5585.82 \mathrm{aA}$ & $6023.02 \mathrm{aA}$ \\
\hline $50 \mathrm{~A} 50$ & $4632.52 \mathrm{bA}$ & $3248.67 \mathrm{aB}$ & $5606.37 \mathrm{aA}$ & $5087.58 \mathrm{aA}$ \\
\hline $1 \mathrm{G} 282$ & $5075.72 \mathrm{bA}$ & $4255.61 \mathrm{aA}$ & $5029.24 \mathrm{aA}$ & $5247.43 \mathrm{aA}$ \\
\hline $50 \mathrm{~A} 70$ & $4237.97 \mathrm{bA}$ & $3621.96 \mathrm{aA}$ & $4450.11 \mathrm{bA}$ & $3874.29 \mathrm{bA}$ \\
\hline $1 \mathrm{G} 220$ & $5024.24 \mathrm{bA}$ & $3561.26 \mathrm{aB}$ & $4485.08 \mathrm{bA}$ & $4950.75 \mathrm{aA}$ \\
\hline $50 \mathrm{~A} 10$ & $4894.08 \mathrm{bA}$ & $3914.86 \mathrm{aA}$ & $4413.13 \mathrm{bA}$ & $4050.66 \mathrm{bA}$ \\
\hline BUSTER & $6186.10 \mathrm{aA}$ & $3892.74 \mathrm{aB}$ & $3178.39 \mathrm{cB}$ & $3448.78 \mathrm{bB}$ \\
\hline
\end{tabular}

Table 6. Foliar macronutrient content $\left(\mathrm{g} \mathrm{kg}^{-1}\right)$ depending on the different sowing dates and phenological stages evaluated.

\begin{tabular}{|c|c|c|c|c|c|}
\hline \multirow{2}{*}{ Nutrient } & \multirow{2}{*}{ Stage } & \multicolumn{4}{|l|}{ Dates } \\
\hline & & 0 DAFS & 17 DAFS & 30 DAFS & $41 \mathrm{DAFS}$ \\
\hline \multirow{3}{*}{$\mathrm{N}$} & 7-8 leaves & $37.14 \mathrm{aB}$ & $39.24 \mathrm{aA}$ & $23.70 \mathrm{bD}$ & $30.44 \mathrm{bC}$ \\
\hline & 9-11 leaves & $32.76 \mathrm{bA}$ & $27.79 \mathrm{bB}$ & $23.27 \mathrm{bD}$ & $26.55 \mathrm{cC}$ \\
\hline & silking & $29.62 \mathrm{cB}$ & $26.11 \mathrm{bD}$ & $27.65 \mathrm{aC}$ & $32.27 \mathrm{aA}$ \\
\hline \multirow{3}{*}{$\mathrm{P}$} & 7-8 leaves & $6.6 \mathrm{aA}$ & $4.46 \mathrm{aB}$ & $2.58 \mathrm{bC}$ & $2.10 \mathrm{cD}$ \\
\hline & 9-11 leaves & $4.52 \mathrm{bA}$ & $2.85 \mathrm{bB}$ & $2.13 \mathrm{cC}$ & $2.45 \mathrm{bD}$ \\
\hline & silking & $3.87 \mathrm{cA}$ & $2.74 \mathrm{bC}$ & $3.10 \mathrm{aB}$ & $3.08 \mathrm{aB}$ \\
\hline \multirow{3}{*}{$\mathrm{K}$} & 7-8 leaves & $32.22 \mathrm{aA}$ & $28.52 \mathrm{aB}$ & $22.12 \mathrm{aC}$ & $18.54 \mathrm{cD}$ \\
\hline & 9-11 leaves & $23.26 \mathrm{bA}$ & $22.54 \mathrm{bB}$ & $20.48 \mathrm{bC}$ & $23.16 \mathrm{aA}$ \\
\hline & silking & $20.23 \mathrm{cC}$ & $23.29 \mathrm{cA}$ & $21.95 \mathrm{cB}$ & $20.34 \mathrm{bC}$ \\
\hline \multirow{3}{*}{$\mathrm{Ca}$} & 7-8 leaves & $4.52 \mathrm{bC}$ & $6.37 \mathrm{bA}$ & $6.12 \mathrm{aB}$ & $6.02 \mathrm{aB}$ \\
\hline & 9-11 leaves & $5.34 \mathrm{aC}$ & $7.12 \mathrm{aA}$ & $5.38 \mathrm{bB}$ & $4.85 \mathrm{bC}$ \\
\hline & silking & $3.12 \mathrm{cC}$ & $3.13 \mathrm{cC}$ & $3.39 \mathrm{cB}$ & $4.60 \mathrm{bA}$ \\
\hline \multirow{3}{*}{$\mathrm{Mg}$} & 7-8 leaves & $1.97 \mathrm{bC}$ & $2.45 \mathrm{bA}$ & $2.04 \mathrm{aB}$ & $1.88 \mathrm{bD}$ \\
\hline & 9-11 leaves & $2.35 \mathrm{aB}$ & $2.83 \mathrm{aA}$ & $2.00 \mathrm{aC}$ & $1.90 \mathrm{bD}$ \\
\hline & silking & $1.81 \mathrm{cC}$ & $1.90 \mathrm{cB}$ & $1.90 \mathrm{aB}$ & $2.29 \mathrm{aA}$ \\
\hline \multirow{3}{*}{$\mathrm{S}$} & 7-8 leaves & $1.50 \mathrm{aA}$ & $1.16 \mathrm{bB}$ & $0.73 \mathrm{bD}$ & $0.87 \mathrm{bC}$ \\
\hline & 9-11 leaves & $1.06 \mathrm{bB}$ & $1.42 \mathrm{aA}$ & $0.60 \mathrm{bD}$ & $0.68 \mathrm{cC}$ \\
\hline & silking & $0.71 \mathrm{cC}$ & $0.69 \mathrm{cC}$ & $0.93 \mathrm{aB}$ & $1.20 \mathrm{aA}$ \\
\hline
\end{tabular}

Uppercase letters in same row and lowercase letters in same column indicate differences according to the Scott-Knott test at a 0.05 level of significance.

Table 7. Phosphorus and calcium foliar content $\left(\mathrm{g} \mathrm{kg}^{-1}\right)$ in grain sorghum hybrids from different sowing dates.

\begin{tabular}{|c|c|c|c|c|c|}
\hline \multirow{2}{*}{ Nutrient } & \multirow{2}{*}{ Hybrids } & \multicolumn{4}{|l|}{ Dates } \\
\hline & & 0 DAFS & 17 DAFS & 30 DAFS & $41 \mathrm{DAFS}$ \\
\hline \multirow{10}{*}{$\mathrm{P}$} & $1 \mathrm{G} 100$ & $5.17 \mathrm{bA}$ & $3.13 \mathrm{bB}$ & $2.65 \mathrm{aC}$ & $2.75 \mathrm{aC}$ \\
\hline & $1 \mathrm{G} 220$ & $5.61 \mathrm{aA}$ & $3.51 \mathrm{aB}$ & $2.79 \mathrm{aC}$ & $2.54 \mathrm{aC}$ \\
\hline & $1 \mathrm{G} 244$ & $4.77 \mathrm{bA}$ & $2.87 \mathrm{bB}$ & $2.44 \mathrm{aC}$ & $2.55 \mathrm{aC}$ \\
\hline & $1 \mathrm{G} 282$ & $4.90 \mathrm{bA}$ & $3.24 \mathrm{bB}$ & $2.70 \mathrm{aC}$ & $2.49 \mathrm{aC}$ \\
\hline & $50 \mathrm{~A} 10$ & $5.03 \mathrm{bA}$ & $3.42 \mathrm{aB}$ & $2.69 \mathrm{aC}$ & $2.56 \mathrm{aC}$ \\
\hline & $50 \mathrm{~A} 50$ & $4.83 \mathrm{bA}$ & $3.30 \mathrm{bB}$ & $2.54 \mathrm{aC}$ & $2.32 \mathrm{aC}$ \\
\hline & $50 \mathrm{~A} 70$ & $5.05 \mathrm{bA}$ & $3.45 \mathrm{aB}$ & $2.64 \mathrm{aC}$ & $2.60 \mathrm{aC}$ \\
\hline & BUSTER & $4.58 \mathrm{bA}$ & $3.72 \mathrm{aB}$ & $2.59 \mathrm{aC}$ & $2.65 \mathrm{aC}$ \\
\hline & EXP001 & $5.02 \mathrm{bA}$ & $3.51 \mathrm{aB}$ & $2.39 \mathrm{aC}$ & $2.39 \mathrm{aC}$ \\
\hline & & 0 DAFS & 17 DAFS & $30 \mathrm{DAFS}$ & 41 DAFS \\
\hline \multirow{9}{*}{$\mathrm{Ca}$} & $1 \mathrm{G} 100$ & $4.45 \mathrm{aB}$ & $5.70 \mathrm{aA}$ & $5.26 \mathrm{aA}$ & $5.65 \mathrm{aA}$ \\
\hline & $1 \mathrm{G} 220$ & $4.26 \mathrm{aB}$ & $5.19 \mathrm{bA}$ & $4.49 \mathrm{bB}$ & $4.60 \mathrm{bB}$ \\
\hline & $1 \mathrm{G} 244$ & $4.05 \mathrm{aD}$ & $5.90 \mathrm{aA}$ & $4.76 \mathrm{bC}$ & $5.34 \mathrm{aB}$ \\
\hline & $1 \mathrm{G} 282$ & $3.99 \mathrm{aC}$ & $5.47 \mathrm{aA}$ & $5.18 \mathrm{aA}$ & $4.84 \mathrm{bB}$ \\
\hline & $50 \mathrm{~A} 10$ & $4.63 \mathrm{aC}$ & $5.73 \mathrm{aA}$ & $5.10 \mathrm{aB}$ & $5.20 \mathrm{aB}$ \\
\hline & $50 \mathrm{~A} 50$ & $4.29 \mathrm{aC}$ & $6.05 \mathrm{aA}$ & $5.14 \mathrm{aB}$ & $5.35 \mathrm{aB}$ \\
\hline & $50 \mathrm{~A} 70$ & $4.60 \mathrm{aB}$ & $5.67 \mathrm{aA}$ & $4.93 \mathrm{bB}$ & $5.27 \mathrm{aA}$ \\
\hline & BUSTER & $4.31 \mathrm{aB}$ & $5.20 \mathrm{bA}$ & $4.90 \mathrm{bA}$ & $5.25 \mathrm{aA}$ \\
\hline & EXP001 & $4.35 \mathrm{aB}$ & $4.95 \mathrm{bA}$ & $4.89 \mathrm{bA}$ & $4.90 \mathrm{bA}$ \\
\hline
\end{tabular}


This indicates that the plants did not show nutritional deficiencies, regardless of sowing time and evaluated hybrid. By analyzing the unfolding of the interaction between stage $x$ sowing dates can be seen that the content of $\mathrm{N}$ in the stadium 7-8 leaves were higher than when the sowing occurs at 17 DAFS, followed by 0,30 and 41 DAFS. In the stadium 9-11 leaves, the greatest concentration occurred when the seeds were sown at 0 DAFS. In the heading the highest concentrations were found when the seeding was done after 41 DAFS (Table 6). When sown at 0 DAFS the content of $\mathrm{N}$ in the leaves decreased with the development of the plant, being higher in the earliest stages of evaluation and lower in the silking. Plants sown at 17 DAFS showed the same trend, however there was no significant difference between the stadiums 9-11 leaves and silking. In sowings at 30 and 41 DAFS the behavior of the plants was different, and the first of them, the levels of 7-8 leaves and 9-11 leaves didn't show difference, and then increased when evaluated at silking. At sowing of 41 DAFS the lowest concentrations were found in the stadium 9-11 leaves and were higher in silking. Borges et al. (2014b) evaluating the nutrient content during the silking obtained similar results. The concentration of $\mathrm{N}$ varied between 21.00 and $23.00 \mathrm{~g} \mathrm{~kg}^{-1}$. Similar results were obtained by Franco (2011) assessing the levels of two sorghum hybrids nutrients in various stages of evaluation, obtained values $23.00 \mathrm{~g} \mathrm{~kg}-1 \mathrm{~N}$ in middle leaves. Related to $\mathrm{P}$, the highest concentration found in the development stages was when the plants were sown at 0 DAFS and generally were lower when the seeding was later. In the first sowing time (0 DAFS) the concentration of $\mathrm{P}$ decreased according to the development plan. At 17 DAFS there was no significant difference between the stadiums 9-11 leaves and silking. When sowing took place after 41 DAFS concentrations increased with the development of the plant, differing in all stages evaluated, except for sowing to 30 DAFS, where the lowest concentration was in the stadium 9-11 leaves and the highest in silking (Table 6). $\mathrm{P}$ values ranged from 2.13 to $6.60 \mathrm{~g} \mathrm{~kg}^{-1}$ in stadiums and evaluated dates of sowing. Borges et al. (2014b) found values varying between 7.42 and $5.83 \mathrm{~g} \mathrm{~kg}^{-1}$, in turn, Franco (2011) gave smaller values, the average being around $2.70 \mathrm{~g} \mathrm{~kg}^{-1}$, both results on the silking. For K the average content ranged from 20.23 to $32.22 \mathrm{~g} \mathrm{~kg}^{-1}$, and the highest concentrations were found in the 7-8 leaf stage, when the plants were grown in 0 DAFS, and in the late sowing the concentration was lower. In the stadium 9-11 leaves, the highest concentrations were found when the seedings were performed at 0 and 41 DAFS. When sown at 17 DAFS the highest concentrations of $\mathrm{K}$ were found in the 7-8 leaf stage. When sown at 0 and 30 DAFS plants decreased in concentration of $\mathrm{K}$ with the development of the plant. After 41 DAFS nutrient contents were lower in 7-8 leaves followed by an increase in 9-11 leaves and reduction in earing (Table 6). The values found in this study were higher than those found by Borges et al (2014b) and Franco (2011) found that on average $15: 00 \mathrm{~g} \mathrm{~kg}^{-1}$ in the silking. The Ca content varied from 3.12 to $7.12 \mathrm{~kg}^{-1} \mathrm{~g}$ and $\mathrm{Mg}$ from 1.81 to $2.83 \mathrm{~g} \mathrm{~kg}^{-1}$ and in general followed the same trends. When the seeds were sown at 17 DAFS, the stages of 7-8 leaves and 9-11 leaves showed the highest concentrations and when sown after 41 DAFS the highest concentration was in the silking stage. The sowing of 0 and 17 DAFS contents increased from 7-8 to 9-11 leaves and leaves at silking decreased under the 7-8 leaf stage. In sowings at 30 and 41 DAFS concentrations of these nutrients decreased with plant development, and for the plants sown at 30 DAFS, Mg concentrations didn't differ in the evaluated stadiums. In sowing after 41 DAFS they were higher in the silking (Table
6). Similar results were obtained by Franco (2011) when evaluating these stadiums. Borges et al. (2014b) found mean values of $4: 40 \mathrm{~g} \mathrm{~kg}^{-1}$ of $\mathrm{Ca}$ and $3.30 \mathrm{~g} \mathrm{~kg}^{-1}$ for $\mathrm{Mg}$ during flowering. The $\mathrm{S}$ concentrations ranged from 0.60 to $1.50 \mathrm{~g}$ $\mathrm{kg}^{-1}$ and the higher ones were observed in the 7-8 leaf stage when sowing DAFS occurred at 0 , to the seeded at 17 DAFS was at most 9-11 leaves stage and 41 DAFS at silking. In plants sown at 0 DAFS concentrations were higher in 7-8 leaves, smaller leaves on 9-11 and last in the silking. For seeded hybrids to 17 DAFS concentration increased from 7-8 to 9-11 leaves at silking and fell under the level of the first stage evaluated. When the seedings were performed at 30 and 41 DAFS plants showed increased concentrations of this nutrient in their development (Table 6).

\section{Evaluation of macronutrients contente $\left(\mathrm{g} \mathrm{Kg}^{-1}\right)$ in different hybrids and different sowing dates}

Regarding the interaction between hybrids $\mathrm{x}$ sowing dates, the $\mathrm{P}$ concentrations ranged $2: 32$ to $5: 37 \mathrm{~g} \mathrm{~kg}^{-1}$ and the highest values occurred at 0 DAFS, decreasing in the other evaluated dates. At 30 and 41 DAFS there was no difference between hybrids (Table 7). When sowing took place at 0 DAFS hybrid 1G220 was what absorbed more P, however to 17 DAFS were $1 \mathrm{G} 220$ hybrids, 50A10, 50A70, BUSTER and EXP001. The hybrids showed no difference in the absorption of $\mathrm{P}$ between them when they were seeded at 30 and 41 DAFS. There are evidences that prove differences in phosphorus uptake in different strains of sorghum, these serving as a genetic basis for breeding programs. These differences in phosphorus uptake, according to these authors, are due to a variety of physiological, morphological and biochemical mechanisms of sorghum plant (Rocha et al., 2010; Rodrigues et al., 2014b). Relative to $\mathrm{Ca}$ in general all hybrids showed higher concentrations of the nutrient when the seeding was done at 17 DAFS and hybrid 1G100, BUSTER and EXP001 concentrations were lower when they were sown at 0 DAFS. The hybrid 50A10, 50A50 and 1G100 were the most absorbed $\mathrm{Ca}$ in other seasons (Table 7). The inadequate supply of $\mathrm{N}$ is a limiting factor to grain yield, since it plays an important role in the biochemical processes of the plant, besides being a constituent of proteins, enzymes, chlorophyll and phytochrome. Under natural conditions the $\mathrm{N}$ concentration are deficient in almost all Brazilian soils, especially in the off-season, because of this nutrient be linked to organic plant compounds, if necessary, its releasing and absorption by plants (Fornasieri Filho et al., 2009). N levels did not vary between the phenological stages evaluated for hybrid 50A10 and 50A70, in turn, the other hybrids showed higher concentrations in the 7-8 leaf stage, decreasing in stages of 9-11 leaves, and this did not present differences in the silking stage. At the stage of 7-8 leaves, the hybrid 1G220 showed the highest concentration of $\mathrm{N}$ and 50A10 and 50A70 were minors. The stadium of 9-11 leaves, except the hybrid EXP001 that showed lower concentrations, the remaining showed statistically equal concentration (Table 8). For Mg, hybrid 1G100, 1G220 and 50A70 showed no significant differences between the evaluated stages, differing from hybrid 1G244, 1G282, 50A10 and 50A50 with highest concentrations in the stadium 9-11 leaves. The concentrations of the BUSTER and Exp001 hybrids differed only in silking, being smaller than the other evaluated stadiums. The BUSTER and EXP001 hybrid had higher Mg concentrations in the 7-8 leaf stage followed by 50A70 and 1G100 and finally the other hybrids. At the stage of 9-11 leaves, the hybrid 1G244, 1G282, 50A50 and 50A70 had the highest concentration followed by BUSTER and $1 \mathrm{G} 100$ and the 
Table 8. Nitrogen and magnesium foliar content $\left(\mathrm{g} \mathrm{kg}^{-1}\right)$ in grain sorghum hybrids from different development stages evaluated.

\begin{tabular}{|c|c|c|c|c|}
\hline \multirow{2}{*}{ Nutrient } & \multirow{2}{*}{ Hybrids } & \multicolumn{3}{|c|}{ Stage } \\
\hline & & 7-8 leaves & 9-11 leaves & silking \\
\hline \multirow{10}{*}{$\mathrm{N}$} & $1 \mathrm{G} 100$ & $33.04 \mathrm{bA}$ & $27.16 \mathrm{aB}$ & $27.21 \mathrm{cB}$ \\
\hline & $1 G 220$ & $36.17 \mathrm{aA}$ & $28.07 \mathrm{aB}$ & $30.28 \mathrm{bB}$ \\
\hline & $1 \mathrm{G} 244$ & $31.64 \mathrm{cA}$ & $28.34 \mathrm{aB}$ & $29.05 \mathrm{cB}$ \\
\hline & $1 \mathrm{G} 282$ & $33.39 \mathrm{bA}$ & $27.22 \mathrm{aB}$ & $27.92 \mathrm{cB}$ \\
\hline & $50 \mathrm{~A} 10$ & $29.54 \mathrm{dA}$ & $27.57 \mathrm{aA}$ & $28.59 \mathrm{cA}$ \\
\hline & $50 \mathrm{~A} 50$ & $34.10 \mathrm{bA}$ & $29.10 \mathrm{aB}$ & $27.45 \mathrm{cB}$ \\
\hline & $50 \mathrm{~A} 70$ & $29.32 \mathrm{dA}$ & $27.95 \mathrm{aA}$ & $29.54 \mathrm{bA}$ \\
\hline & BUSTER & $33.72 \mathrm{bA}$ & $27.36 \mathrm{aB}$ & $31.98 \mathrm{aA}$ \\
\hline & EXP001 & $32.76 \mathrm{bA}$ & $25.59 \mathrm{bB}$ & $28.21 \mathrm{cB}$ \\
\hline & & 7-8 leaves & 9-11 leaves & silking \\
\hline \multirow{9}{*}{$\mathrm{Mg}$} & $1 \mathrm{G} 100$ & $2.15 \mathrm{bA}$ & $2.23 \mathrm{bA}$ & $2.01 \mathrm{aA}$ \\
\hline & $1 \mathrm{G} 220$ & $2.00 \mathrm{cA}$ & $2.10 \mathrm{cA}$ & $2.08 \mathrm{aA}$ \\
\hline & $1 \mathrm{G} 244$ & $1.93 \mathrm{cB}$ & $2.29 \mathrm{aA}$ & $1.92 \mathrm{bB}$ \\
\hline & $1 \mathrm{G} 282$ & $2.00 \mathrm{cB}$ & $2.32 \mathrm{aA}$ & $2.00 \mathrm{aB}$ \\
\hline & $50 \mathrm{~A} 10$ & $1.97 \mathrm{cB}$ & $2.24 \mathrm{bA}$ & $1.91 \mathrm{bB}$ \\
\hline & $50 \mathrm{~A} 50$ & $2.06 \mathrm{cB}$ & $2.38 \mathrm{aA}$ & $2.08 \mathrm{aB}$ \\
\hline & $50 \mathrm{~A} 70$ & $2.15 \mathrm{bA}$ & $2.28 \mathrm{aA}$ & $2.11 \mathrm{aA}$ \\
\hline & BUSTER & $2.24 \mathrm{aA}$ & $2.20 \mathrm{bA}$ & $1.89 \mathrm{bB}$ \\
\hline & EXP001 & $2.29 \mathrm{aA}$ & $2.35 \mathrm{aA}$ & $1.75 \mathrm{cB}$ \\
\hline
\end{tabular}

Table 9. Chlorophyll content (SPAD index) for grain sorghum hybrids from different sowing times and evaluated at different stadiums.

\begin{tabular}{|c|c|c|c|c|}
\hline \multirow{2}{*}{ Dates } & \multirow{2}{*}{ Hybrids } & \multicolumn{3}{|c|}{ Stage } \\
\hline & & $7-8$ leaves & 9-11 leaves & silking \\
\hline \multirow{9}{*}{0 DAFS } & $1 \mathrm{G} 100$ & $50.38 \mathrm{aA}$ & $52.83 \mathrm{aA}$ & $41.72 \mathrm{bB}$ \\
\hline & $1 \mathrm{G} 220$ & $51.13 \mathrm{aA}$ & $53.39 \mathrm{aA}$ & $45.39 \mathrm{aB}$ \\
\hline & $1 \mathrm{G} 244$ & $48.60 \mathrm{aA}$ & $51.25 \mathrm{aA}$ & $43.10 \mathrm{bB}$ \\
\hline & $1 \mathrm{G} 282$ & $48.75 \mathrm{aA}$ & $49.44 \mathrm{aA}$ & $40.39 \mathrm{bB}$ \\
\hline & $50 \mathrm{~A} 10$ & $50.23 \mathrm{aA}$ & $51.58 \mathrm{aA}$ & $40.88 \mathrm{bB}$ \\
\hline & $50 \mathrm{~A} 50$ & $49.56 \mathrm{aA}$ & $52.36 \mathrm{aA}$ & $42.70 \mathrm{bB}$ \\
\hline & $50 \mathrm{~A} 70$ & $49.11 \mathrm{aB}$ & $52.12 \mathrm{aA}$ & $46.27 \mathrm{aB}$ \\
\hline & BUSTER & $51.14 \mathrm{aA}$ & $51.50 \mathrm{aA}$ & $48.90 \mathrm{aA}$ \\
\hline & EXP001 & $49.03 \mathrm{aB}$ & $52.62 \mathrm{aA}$ & $40.52 \mathrm{bC}$ \\
\hline \multirow{9}{*}{17 DAFS } & $1 \mathrm{G} 100$ & $49.22 \mathrm{aA}$ & $47.79 \mathrm{bA}$ & $38.81 \mathrm{~dB}$ \\
\hline & $1 \mathrm{G} 220$ & $49.49 \mathrm{aA}$ & $50.85 \mathrm{aA}$ & $45.76 \mathrm{bB}$ \\
\hline & $1 \mathrm{G} 244$ & $48.30 \mathrm{aA}$ & $48.10 \mathrm{bA}$ & $43.52 \mathrm{cB}$ \\
\hline & $1 \mathrm{G} 282$ & $45.48 \mathrm{bA}$ & $45.31 \mathrm{bA}$ & $40.46 \mathrm{~dB}$ \\
\hline & $50 \mathrm{~A} 10$ & $50.19 \mathrm{aA}$ & $49.97 \mathrm{aA}$ & $41.10 \mathrm{cB}$ \\
\hline & $50 \mathrm{~A} 50$ & $49.42 \mathrm{aA}$ & $47.59 \mathrm{bA}$ & $41.70 \mathrm{cB}$ \\
\hline & $50 \mathrm{~A} 70$ & $46.23 \mathrm{bA}$ & $47.61 \mathrm{bA}$ & $43.07 \mathrm{cB}$ \\
\hline & BUSTER & $51.58 \mathrm{aA}$ & $50.35 \mathrm{aA}$ & $51.72 \mathrm{aA}$ \\
\hline & EXP001 & $48.74 \mathrm{aA}$ & $47.01 \mathrm{bA}$ & $38.75 \mathrm{~dB}$ \\
\hline \multirow{9}{*}{30 DAFS } & $1 \mathrm{G} 100$ & $41.79 \mathrm{aA}$ & $43.21 \mathrm{bA}$ & $43.23 \mathrm{bA}$ \\
\hline & $1 \mathrm{G} 220$ & $40.73 \mathrm{bC}$ & $45.49 \mathrm{aB}$ & $48.42 \mathrm{aA}$ \\
\hline & $1 \mathrm{G} 244$ & $39.05 \mathrm{bB}$ & $44.11 \mathrm{bA}$ & $46.48 \mathrm{aA}$ \\
\hline & $1 \mathrm{G} 282$ & $39.32 \mathrm{bC}$ & $44.19 \mathrm{bB}$ & $47.25 \mathrm{aA}$ \\
\hline & $50 \mathrm{~A} 10$ & $40.79 \mathrm{bB}$ & $46.98 \mathrm{aA}$ & $45.22 \mathrm{bA}$ \\
\hline & $50 \mathrm{~A} 50$ & $42.66 \mathrm{aA}$ & $44.68 \mathrm{aA}$ & $44.00 \mathrm{bA}$ \\
\hline & $50 \mathrm{~A} 70$ & $42.66 \mathrm{aB}$ & $45.88 \mathrm{aA}$ & $48.30 \mathrm{aA}$ \\
\hline & BUSTER & $43.54 \mathrm{aB}$ & $41.25 \mathrm{bB}$ & $46.20 \mathrm{aA}$ \\
\hline & EXP001 & $41.68 \mathrm{aB}$ & $46.26 \mathrm{aA}$ & $44.70 \mathrm{bA}$ \\
\hline \multirow{9}{*}{41 DAFS } & $1 \mathrm{G} 100$ & $47.95 \mathrm{aA}$ & $49.38 \mathrm{bA}$ & $50.30 \mathrm{aA}$ \\
\hline & $1 \mathrm{G} 220$ & $47.34 \mathrm{aB}$ & $53.45 \mathrm{aA}$ & $53.05 \mathrm{aA}$ \\
\hline & $1 \mathrm{G} 244$ & $47.26 \mathrm{aB}$ & $50.93 \mathrm{bA}$ & $51.08 \mathrm{aA}$ \\
\hline & $1 \mathrm{G} 282$ & $45.18 \mathrm{bB}$ & $49.04 \mathrm{bA}$ & $45.63 \mathrm{bB}$ \\
\hline & $50 \mathrm{~A} 10$ & $48.63 \mathrm{aA}$ & $50.21 \mathrm{bA}$ & $51.12 \mathrm{aA}$ \\
\hline & $50 \mathrm{~A} 50$ & $45.58 \mathrm{bB}$ & $50.10 \mathrm{bA}$ & $49.73 \mathrm{aA}$ \\
\hline & $50 \mathrm{~A} 70$ & $43.03 \mathrm{bB}$ & $50.68 \mathrm{bA}$ & $48.80 \mathrm{bA}$ \\
\hline & BUSTER & $48.50 \mathrm{aB}$ & $54.34 \mathrm{aA}$ & $50.16 \mathrm{aB}$ \\
\hline & EXP001 & $46.54 \mathrm{aB}$ & $50.83 \mathrm{bA}$ & $48.52 \mathrm{bB}$ \\
\hline
\end{tabular}

Uppercase letters in same row and lowercase letters in same column indicate differences according to the Scott-Knott test at a 0.05 level of significance. 
Table 10. Chlorophyll content (SPAD index) for grain sorghum hybrids from different sowing times and evaluated at different stadiums.

\begin{tabular}{|c|c|c|c|c|c|}
\hline \multirow{2}{*}{ Stage } & \multirow{2}{*}{ Hybrids } & \multicolumn{4}{|c|}{ Dates } \\
\hline & & 0 DAFS & 17 DAFS & 30 DAFS & 41 DAFS \\
\hline \multirow{9}{*}{ 7-8 leaves } & $1 \mathrm{G} 100$ & $50.38 \mathrm{~A}$ & $49.22 \mathrm{~A}$ & $41.79 \mathrm{~B}$ & $47.95 \mathrm{~A}$ \\
\hline & $1 \mathrm{G} 220$ & $51.13 \mathrm{~A}$ & $49.49 \mathrm{~A}$ & $40.73 \mathrm{~B}$ & $47.34 \mathrm{~A}$ \\
\hline & $1 \mathrm{G} 244$ & $48.60 \mathrm{~A}$ & $48.30 \mathrm{~A}$ & $39.05 \mathrm{~B}$ & $47.26 \mathrm{~A}$ \\
\hline & $1 \mathrm{G} 282$ & $48.75 \mathrm{~A}$ & $45.48 \mathrm{~B}$ & $39.32 \mathrm{C}$ & $45.18 \mathrm{~B}$ \\
\hline & $50 \mathrm{~A} 10$ & $50.23 \mathrm{~A}$ & $50.19 \mathrm{~A}$ & $40.79 \mathrm{~B}$ & $48.63 \mathrm{~A}$ \\
\hline & $50 \mathrm{~A} 50$ & $49.56 \mathrm{~A}$ & $49.42 \mathrm{~A}$ & $42.66 \mathrm{~B}$ & $45.58 \mathrm{~B}$ \\
\hline & $50 \mathrm{~A} 70$ & $49.11 \mathrm{~A}$ & $46.23 \mathrm{~A}$ & $42.66 \mathrm{~B}$ & $43.03 \mathrm{~B}$ \\
\hline & BUSTER & $51.14 \mathrm{~A}$ & $51.58 \mathrm{~A}$ & $43.54 \mathrm{~B}$ & $48.50 \mathrm{~A}$ \\
\hline & EXP001 & $49.03 \mathrm{~A}$ & $48.74 \mathrm{~A}$ & $41.68 \mathrm{~B}$ & $46.54 \mathrm{~A}$ \\
\hline \multirow{9}{*}{ 9-11 leaves } & $1 \mathrm{G} 100$ & $52.83 \mathrm{~A}$ & $47.79 \mathrm{~B}$ & $43.21 \mathrm{C}$ & $49.38 \mathrm{~B}$ \\
\hline & $1 \mathrm{G} 220$ & $53.39 \mathrm{~A}$ & $50.85 \mathrm{~A}$ & $45.49 \mathrm{~B}$ & $53.45 \mathrm{~A}$ \\
\hline & $1 \mathrm{G} 244$ & $51.25 \mathrm{~A}$ & $48.10 \mathrm{~A}$ & $44.11 \mathrm{~B}$ & $50.93 \mathrm{~A}$ \\
\hline & $1 \mathrm{G} 282$ & $49.44 \mathrm{~A}$ & $45.31 \mathrm{~B}$ & $44.19 \mathrm{~B}$ & $49.04 \mathrm{~A}$ \\
\hline & $50 \mathrm{~A} 10$ & $51.58 \mathrm{~A}$ & $49.97 \mathrm{~A}$ & $46.98 \mathrm{~B}$ & $50.21 \mathrm{~A}$ \\
\hline & $50 \mathrm{~A} 50$ & $52.36 \mathrm{~A}$ & $47.59 \mathrm{~B}$ & $44.68 \mathrm{~B}$ & $50.10 \mathrm{~A}$ \\
\hline & $50 \mathrm{~A} 70$ & $52.12 \mathrm{~A}$ & $47.61 \mathrm{~B}$ & $45.88 \mathrm{~B}$ & $50.68 \mathrm{~A}$ \\
\hline & BUSTER & $51.50 \mathrm{~B}$ & $50.35 \mathrm{~B}$ & $41.25 \mathrm{C}$ & $54.34 \mathrm{~A}$ \\
\hline & EXP001 & $52.62 \mathrm{~A}$ & $47.01 \mathrm{~B}$ & $46.26 \mathrm{~B}$ & $50.83 \mathrm{~A}$ \\
\hline \multirow{9}{*}{ Silking } & $1 \mathrm{G} 100$ & $41.72 \mathrm{~B}$ & $38.81 \mathrm{C}$ & $43.23 \mathrm{~B}$ & $50.30 \mathrm{~A}$ \\
\hline & $1 \mathrm{G} 220$ & $45.39 \mathrm{~B}$ & $45.76 \mathrm{~B}$ & $48.42 \mathrm{~B}$ & $53.05 \mathrm{~A}$ \\
\hline & $1 \mathrm{G} 244$ & $43.10 \mathrm{C}$ & $43.52 \mathrm{C}$ & $46.48 \mathrm{~B}$ & $51.08 \mathrm{~A}$ \\
\hline & $1 \mathrm{G} 282$ & $40.39 \mathrm{~B}$ & $40.46 \mathrm{~B}$ & $47.25 \mathrm{~A}$ & $45.63 \mathrm{~A}$ \\
\hline & $50 \mathrm{~A} 10$ & $40.88 \mathrm{C}$ & $41.10 \mathrm{C}$ & $45.22 \mathrm{~B}$ & $51.12 \mathrm{~A}$ \\
\hline & $50 \mathrm{~A} 50$ & $42.70 \mathrm{~B}$ & $41.70 \mathrm{~B}$ & $44.00 \mathrm{~B}$ & $49.73 \mathrm{~A}$ \\
\hline & $50 \mathrm{~A} 70$ & $46.27 \mathrm{~A}$ & $43.07 \mathrm{~B}$ & $48.30 \mathrm{~A}$ & $48.80 \mathrm{~A}$ \\
\hline & BUSTER & $48.90 \mathrm{~A}$ & $51.72 \mathrm{~A}$ & $46.20 \mathrm{~B}$ & $50.16 \mathrm{~A}$ \\
\hline & EXP001 & $40.52 \mathrm{C}$ & $38.75 \mathrm{C}$ & $44.70 \mathrm{~B}$ & $48.52 \mathrm{~A}$ \\
\hline
\end{tabular}

Distintic letters in the line indicate differences according to the Scott-Knott test at a 0.05 level of significance.

Table 11. Correlations between macronutrient content and SPAD index in different stadiums.

\begin{tabular}{|c|c|c|c|c|c|c|}
\hline Correlations & $\mathrm{N}$ & $\mathrm{P}$ & $\mathrm{K}$ & $\mathrm{Ca}$ & $\mathrm{Mg}$ & $S$ \\
\hline \multicolumn{7}{|l|}{$7-8$ leaves } \\
\hline Spad & $0.63^{*}$ & $0.57 *$ & $0.47 *$ & $-0.26^{*}$ & $0.21 *$ & $0.47 *$ \\
\hline \multicolumn{7}{|l|}{ 9-11 leaves } \\
\hline Spad & $0.52 *$ & $0.55^{*}$ & $0.28^{*}$ & $-0.16^{\mathrm{ns}}$ & $0.09^{\mathrm{ns}}$ & $0.15^{\mathrm{ns}}$ \\
\hline \multicolumn{7}{|l|}{ Silking } \\
\hline Spad & $0.61 *$ & $0.01^{\mathrm{ns}}$ & $-0.08^{\mathrm{ns}}$ & $0.43^{*}$ & $0.46^{*}$ & $0.53 *$ \\
\hline
\end{tabular}

lowest was $1 \mathrm{G} 220$. In heading the largest contents of 50A70 hybrids, 1G100, 1G220, $1 \mathrm{G} 282$ and $1 \mathrm{G} 244$ followed by 50A50, 50A10 and BUSTER and the lowest for the EXP001 (Table 8). The SPAD index has been used to quantify the chlorophyll content, and is characterized by rapid, simple and non-destructive reading material. The chlorophyll content is a good indicator of the nutritional status, as well as most of the nitrogen of the cells are associated with the chlorophyll molecules (Lopez-Cantarero et al., 1994).

\section{Evaluation of SPAD index in different hybrids, phenological stages and sowing dates}

Analyzing the unfolding of the interaction sowing $\mathrm{x}$ hybrid phenological stages can be observed when the seedling was done in the first period (0 DAFS), the SPAD index values ranged from 40.39 to 53.39 . In general, the hybrids showed differences in SPAD index between silking and the other evaluated stages (Table 9). The hybrid BUSTER had no difference in content between stages evaluated, the hybrid 50A70 had statistically equal values between stages 7-8 leaves and silking stage and higher in 9-11 leaves. The hybrid EXP001 in turn, had higher rates of 9-11 leaves than 7-8 leaves and silking these values were lower than in the first stage of evaluation. These rates did not vary between hybrids in stage 7-8 leaves and 9-11 leaves, but the 1G220 at silking hybrids, 50A70 and BUSTER showed the highest concentrations (Table 9). In 17 DAFS the SPAD values ranged from 38.81 to 51.72 among the evaluated stadiums. They did not vary significantly between the stages 7-8 leaves and 9-11 leaves, however were higher than bolting for all hybrids except the hybrid BUSTER that there was no difference in the SPAD index between stages. In stage 7-8 leaves the hybrids showed no difference in the levels, at the stage of 9-11 leaves the BUSTER hybrids, 50A10 and 1G220 showed the highest rates SPAD. In silking, BUSTER showed higher content, followed by 1G220. The EXP001 and 1G100 hybrid had the lowest rates (Table 9). When sowing took place at 30 DAFS, indices showed values between 39.05 and 48.42. Hybrid 1 G100 and 50A50 showed no differences in SPAD indexes between stages evaluated, and generally, for the other hybrids this amount was increased according to the development of plants. In stage of 7-8 leaves hybrids 1G100, 50A50, 50A70, BUSTER and EXP001 showed higher SPAD indexes. In stage 9-11 leaves were 1G220 hybrid 50A10, 50A50, 50A70 and EXP001 the highest content in the silking 
hybrids were 1G220, 1G244, 1G282, 50A70 and BUSTER (Table 9). Regarding sowing after 41 DAFS, the values ranged between 43.03 and 54.34. Hybrid 1G100 and 50A10 showed no significant differences among the phenological stages evaluated. The 1G282 hybrids, 50A50 and 50A70 showed lower rates in the 7-8 leaf stage, higher in 9-11 leaves and after the silking. The 1G282 hybrids, BUSTER and EXP001 increased 7-8 leaves values for 9-11 leaves and silking fell to statistically equal to the stage 7-8 leaves values. At the stage of 7-8 leaves the 1G282 hybrids, 50A50 and 50A70 showed the lowest rates. At the stage of 9-11 leaves, the highest levels were for 1G220 and BUSTER hybrids. In silking only 1G282, 50A70 and EXP001 had lower levels than the others did (Table 9). According to Magalhães et al. (2009) evaluated the SPAD index in maize lines submitted to water stress during flowering found values ranging from 42.00 to 47.00 SPAD for plants without stress. Zotarelli (2003) evaluating corn hybrids in bloom after rotation with oats in Londrina, found SPAD values in average of 56.00. Argenta et al. (2001) evaluating the SPAD index in two corn hybrids in different growth stages found values ranging between 44.00 and 48.50 at the stadium 6-7 leaves, 48.00 to 57.50 in the stadium 10-11 leaves and 45.00 and 52.00 in the silking, being similar to found in this experiment. According to the Table 10, it can be seen that in stage 7-8 leaves most of the hybrids were planted when 30 DAFS SPAD index had lower values than the other sowing dates. The 50A50 and 50A70 hybrid also showed lower values when sowing occurred after 41 DAFS. When analyzed the stage of 9-11 leaves most hybrids showed behavior similar to earlier stage, so lower values when sowing was performed 30 DAFS. The 1G282 hybrids, 50A50, 50A70 and BUSTER also showed lower values when seeded at 17 DAFS. When the seeds were sown in its first season (26/02) and 41 DAFS most hybrids showed the highest rates SPAD. In silking, in general, the hybrids were sown when the 41 DAFS showed higher values of SPAD index. Hybrid 1G100, 1G244, 1G282, 50A10, 50A70 and EXP001 showed lower values when seeded at 17 DAFS.

\section{Correlation between macronutrient levels and SPAD index}

It was accomplished the correlations between the levels of macronutrients and SPAD index at the different stages. As can be seen in the state of 7-8 leaves there was a significant linear correlation between the SPAD indexes and all evaluated macronutrients, being positive for all except for $\mathrm{Ca}$. The negative correlation observed in this nutrient can be explained by its low mobility plants (Epstein et al., 2004). At the stage of 9-11 leaves, the correlation was significant between SPAD index and the contents of N, P and K. When performed at silking, the correlations were significant for $\mathrm{N}$, $\mathrm{Ca}, \mathrm{Mg}$ and $\mathrm{S}$ (Table 11). Similar data were obtained by Argenta et al. (2001) evaluating the correlation between nitrogen content and SPAD values in two corn hybrids, and in the early stages it doesn't show any correlation between these variables, but in stages of 10-11 leaves and silking the correlation was positive. Rocha et al. (2005) evaluated the correlation between nitrogen content and SPAD index for three corn hybrids observed positive correlations between nitrogen content and SPAD index in the stadiums of 4 leaves, 8 leaves and silking. Neves et al. (2005) examined the use of SPAD-502 in the evaluation of $\mathrm{N}, \mathrm{Fe}, \mathrm{S}$ and $\mathrm{Mn}$ in herbaceous cotton plants and observed positive correlations between the device reading and the $\mathrm{N}$ leaf content and negative correlations with $\mathrm{S}$ contents. There are few studies in the literature, which are performed correlations of nutrient content with the SPAD index values, thus requiring greater study of these correlations.

\section{Materials and Methods}

\section{Experimental site and treatments}

The experiments were conducted in the Regional Pole of the Technological Agropecuary Paulista Agence (APTA), in the city of Votuporanga, São Paulo $\left(20^{\circ} 28^{\prime} \mathrm{S}\right.$ and $\left.50^{\circ} 04^{\prime} \mathrm{W}\right)$ and at an altitude of $440 \mathrm{~m}$. The soil is characterized as Dusky Red Latosol (oxisol), with a sandy texture and soft relief. The chemical attributes of the soil are shown in Table 1 . According to Prado, Jorge and Menk (1999), the predominant weather in the Votuporanga region is tropical wet and dry or savanna climate (Aw; Köppen), with a definite dry season, an annual average temperature of $22{ }^{\circ} \mathrm{C}$, and a medium temperature range from $18,4{ }^{\circ} \mathrm{C}$ to $23,9{ }^{\circ} \mathrm{C}$. The annual medium rainfall is $1.344 \mathrm{~mm}$, with $74 \%$ of the rain happening from October to March, and 26\% from April to September. Precipitation and medium temperature during the experimental period are indicated in Figure 1. The experiment was conducted in a conventional cultivation system, which required plowing and disking. The sowing and coverage fertilization were the same for all the sowing dates. The sowing fertilization was carried out with $300 \mathrm{~kg} \mathrm{ha}^{-1}$ of the formulated $08-28-16$, and the coverage was carried out with $300 \mathrm{~kg} \mathrm{ha}^{-1}$ of ammonium sulfate. The plants received this fertilization in the same phenological stages (5 leaves completed expanded), independently of the sowing date, approximately 18 days after the emergence of the seedlings (Table 2). In the experiment were used 9 grain sorghum hybrids, adapted for sowing in the Northwest part on the State of São Paulo.

\section{Evaluated characteristics}

The following agronomic characteristics were evaluated: plant height $(\mathrm{cm})$ that was determined by measuring the distance between the base of the plants at ground level (randomly chosen five plants per plot) and the base of the panicle; flowering (days) assessing the amount of days between sowing and flowering, considering the flowering portion when, in over $50 \%$ of the plants, the middle third of the flower panicle entered anthesis and productivity $\left(\mathrm{kg} \mathrm{ha}^{-1}\right)$. For this last determination, parcels of grain were picked and measured for their humidity, after the weight was corrected for the grain humidity degree to $13 \%$, according to the formula $\mathrm{Mc}=\mathrm{Mo}(100-\mathrm{u} 0) 87^{-1}$; where $\mathrm{Mc}$ and Mo were the corrected and observed mass, respectively; u0 was the observed humidity; It was also accomplished chlorophyll measures through the SPAD index and determination of macronutrients contents. To measure chlorophyll, it was used the chlorophyll brand SPAD-502 Konica Minolta. The chlorophyll meter readings and the determination of the leaves macronutrient contents were carried out in stages of 7 8 expanded leaves (considering last expanded leaf); 9-11 expanded leaves and Heading stages leaves (considering the flag leaf). For readings with chlorophyll, five plants were chosen aleatory in each plot and they have been identified for the reading of chlorophyll contents being performed in the same plants in different stages of evaluated phenology. In each phenological stage three evaluations were made per leaf (in the middle of the base $2 \mathrm{~cm}$ and $2 \mathrm{~cm}$ from the tip of the leaf). After evaluation, the selected leaves, for each phenological stage, were taken, identified and placed in paper bags for drying at 60 degrees until they reach balance 
weights. Afterward, the samples were transported to the Earth laboratory in the Federal University of Uberlândia, according to the methods of Malavolta, Vitti and Oliveira (1997). Nitrogen content was determined by the semimicro-Kjeldahl distillation method, and other nutrients were extracted in a nitric-perchloric solution. From the extracted solution, the $\mathrm{Ca}$ and $\mathrm{Mg}$ contents are determined with spectrophotometry of the atomic absorption; P and S, from spectrophotometry; and $\mathrm{K}$, from flame photometry.

\section{Experimental design and statistical analysis}

The experiment was conducted in casually delineated blocks, with nine treatments and four repetitions. The portions were designated with 4 lines, 5 meters in length, and the two central lines were considered as the useful areas. Nine grain sorghum hybrids were evaluated, constituting the different treatments, for each of the different sowing dates. Each date was considered an individual experiment. The levels of macronutrients and SPAD indices were evaluated at three different stages within the plant cycle, characterizing an experiment on an analysis of split plot (development stage subplot), with a factor in the plot (hybrid x sowing time). All features analyzed were accomplished variance analysis related to the different sowing dates, and afterward, a joint analysis of the data (Supplementary Table 1 and 2) was performed. Those data where the medium square ratio of each analysis of variance did not exceed the relation 7:1 were used. The " $F$ " test was performed to determine levels of significance of 0.05 and 0.01 for the analysis of variance. When these tests were significant, the averages were compared with the Scott-Knott test at the 0.05 level of probability.

Finally, it was calculated the Pearson correlation coefficients for the variables macronutrient and SPAD index according to "t" test of Student 0.05 and 0.01 significance level.

\section{Conclusions}

The productivity of grain sorghum hybrids depends on the sowing dates. In general, the macronutrient content in different growth stages vary according to the sowing date, presenting the following descending order of concentration: $\mathrm{N}>\mathrm{K}>\mathrm{P}>\mathrm{Ca}>\mathrm{Mg}>\mathrm{S}$. The chlorophyll index values (SPAD) have positive linear correlations with the nitrogen content in phenological stages evaluated.

\section{Acknowledgments}

The authors thank FAPEMIG, CNPq and CAPES for the financial support.

\section{References}

Almeida Filho JED, Tardin FD, Souza SÂD, Godinho VDPC, Cardoso MJ (2010). Desempenho agronômico e estabilidade fenotípica de híbridos de sorgo granífero. Rev Bras Milho e Sorgo. 9 (01): 51-64.

Almeida Filho JED, Tardin FD, Daher RF, Silva KJD, Xavier Neto JB, Bastos E, Beserra de Menezes C (2014). Avaliação agronômica de híbridos de sorgo granífero em diferentes regiões produtoras do brasil. Rev Bras Milho e Sorgo. 13(1): 82-95.

Argenta G, Silva, PD, Bortolini CG, Forsthofer EL, Strieder ML (2001). Relação da leitura do clorofilômetro com os teores de clorofila extraível e de nitrogênio na folha de milho. Rev Bras Fisiol Veg. 13(2): 158-167.
Baumhardt RL, Howell TA (2006). Seeding practices, cultivar maturity, and irrigation effects on simulated grain sorghum yield. Agron J. 98(3): 462-470.

Barbero LM, Teixeira AM, Macedo Junior GL, Basso KC, Silveira JPF, Basso FC. Viabilidade técnica e econômica dos grãos de sorgo para monogástricos. (2014) Info Agropec, Belo Horizonte. 35 (278): 33-40.

Borges WLB, de Freitas RS, Mateus, GP, de Sá ME, Alves MC (2014). Absorção de nutrientes e alterações químicas em Latossolos cultivados com plantas de cobertura em rotação com soja e milho. Rev Bras Ciênc Solo. 252-261.

Borghi E, Crusciol CAC, Nascente AS, Sousa VV, Martins PO, Mateus GP, Costa C (2013). Sorghum grain yield, forage biomass production and revenue as affected by intercropping time. Eur J Agron. 51: 130-139.

Borghi E, Bortolon L, Avanzi JC, Bortolon ESO, Ummus ME, Neto MMG, Costa RV (2014). Desafios das Novas Fronteiras Agrícolas de Produção de Milho e Sorgo no Brasil-Desafios da Região do MATOPIBA In: Karam D, Magalhães PC (ed.), Eficiência nas cadeias produtivas e o abastecimento global, Sete Lagoas

Bull LT, Cantarella H (1993) Cultura do milho: fatores que afetam a produtividade. Piracicaba.

Cantarella H, Raij BV, Sawazaki E (1997) Sorgo-granífero, forrageiro e vassoura. In: Raij BV, Cantarella $\mathrm{H}$, Quaggio JA, Furlani AMC (eds). Recomendações de adubação e calagem para o Estado de São Paulo. 2.ed. Campinas: IAC. p.66-67. Boletim Técnico, 100

Conab (2014) Companhia Nacional de Abastecimento. Acompanhamento da safra brasileira: grãos, oitavo levantamento Brasília

Embrapa (2009) Empresa Brasileira de Pesquisa Agropecuária. Manual de análises químicas de solos, plantas e fertilizantes. (2 ed) Brasília, DF.

Epstein E, Bloom AJ (2006). Nutrição mineral de plantas, princípios e perspectivas. (2ed) Londrina, Editora Planta

Fernandes EA, Carvalho CMC, Litz FH, Martins JMS, Silveira MM, Silva MCA, Barbero LM (2014) Viabilidades técnica e econômica da utilização de grãos de sorgo para monogástricos. Info Agropec, Belo Horizonte. 35 (278): 22-32.

Franco AAN (2011) Marcha de absorção e acúmulo de nutrientes na cultura do sorgo. Dissertação (Mestrado em Produção Vegetal) -Programa de Pós-Graduação em Produção Vegetal no Semi-Árido, Universidade Estadual de Montes Claros -Unimontes, Janaúba.

Fornasieri filho D, Fornasieri JL (2009) Manual da cultura do sorgo. Jaboticabal Funep.

Heckler JC (2002). Sorgo e girassol no outono-inverno, em sistema plantio direto, no Mato Grosso do Sul, Brasil. Ciênc Rural. 32(03): 517-520.

Lazzarotto C (2003). Época de semeadura e riscos climáticos para o sorgo granífero, no outono-inverno, em São Gabriel do Oeste, MS. Comun tec Embrapa Agropecu Oeste.

Lima JD, Sakai RK, Aldrighi M, Sakai M (2010). Arranjo espacial, densidade e época de semeadura no acúmulo de matéria seca e nutrientes de três adubos verdes. Pesqui Agropecu Trop. 40(4): 531-540.

Lopez-cantarero I, Lorente FA, Romero L (1994) Are chlorophylls good indicators of nitrogen and phosphorus levels. J Plant Nutr Nova Iorque 17: 979-990.

Malavolta E, Vitti GC, Oliveira SA (1997) Avaliação do estado nutricional das plantas: princípios e aplicações (2 ed) Piracicaba, SP, Brasil. 
Magalhães PC, Souza TCD, Albuquerque PEPD, Karam D, Magalhães MM, Cantão FRDO (2010). Caracterização ecofisiológica de linhagens de milho submetidas a baixa disponibilidade hídrica durante o florescimento. Rev Bras Milho e Sorgo. 8(03).

May A, Parrella RAC, Damasceno CMB, Simeone MLF (2014) Sorgo como matéria-prima para produção de bioenergia: etanol e cogeração Info Agropecu, Belo Horizonte. 35(278):14-20.

Marin FR, Pandorfi H, Sentelhas PC, Camargo MD, Hernandez FBT (2006). Perda de produtividade potencial da cultura do sorgo no Estado de São Paulo. Bragantia. 65(1):157-162.

Miranda NO, Góes GB, Neto RCA, Lima AS (2010). Sorgo forrageiro em sucessão a adubos verdes na região de Mossoró, RN. Rev Bras Ciênc Agrar. 5(2):202-206.

Moreira FRDC, Costa AN, Martins TDD, Silva JHVD, Medeiros HRD, Cruz GRBD (2014). Substituição parcial do milho por sorgo granífero na alimentação de suínos nas fases de creche, crescimento e terminação. Rev Bras Saúde e Prod Animal. 15(1).

Neves OSC, Carvalho JG, Martins FAD, Pádua TRP, Pinho PJ (2005) Uso do SPAD-502 na avaliação dos teores foliares de clorofila, nitrogênio, enxofre, ferro e manganês do algodoeiro herbáceo. Pesqui Agropecu Bras, Brasília. 40(5):517-521.

Prado HD, Jorge J, Menk J. (1999) Levantamento pedológico detalhado e caracterização fisico-hídrica dos solos da Estação Experimental de Agronomia de Votuporanga (SP). Campinas, Instituto Agronômico de Campinas, 1999. 24p. Boletim Científico,42.

Ribeiro AT, Guimarães PTG, Alvarez VH (1999). Recomendação para o uso de corretivos e fertilizantes em Minas Gerais. $5^{\text {a }}$ Aproximação Viçosa. CFSEMG. 359p.

Ribas, P. M. (2014) Origem e importância econômica In: Borem A, Pimentel LD, Parrella RAC (eds) Sorgo do plantio à colheita. Viçosa. MG :9-36.

Rocha RNC, Galvão JCC, Teixeira PC, Miranda GV, Agnes EL, Pereira PRG, Leite UT (2010). Relação do índice SPAD, determinado pelo clorofilômetro, com teor de nitrogênio na folha e rendimento de grãos em três genótipos de milho. Rev Bras Milho e Sorgo. 4(02).

Rocha MCD, Miranda GV, Vasconcelos MJV, Magalhães PC, Carvalho Junior GAD, Silva LA, Schaffert RE (2010). Caracterização da morfologia radicular de genótipos contrastantes de sorgo em baixo e alto níveis de fósforo. Rev Bras Milho e Sorgo. 9(01):65-78.
Rodrigues JAS, Tomich TR, Gonçalves LC, Albuquerque CJB, Guimaraes AS, Fernandes LO, Paes JMV (2014) Sorgo Forrageiro para silagem, corte e pastejo. Info Agropecu, Belo Horizonte. 35(278):50-62(a).

Rodrigues F, Magalhães JV, Guimarães CT, Tardin FD, Schaffert RE (2014) Seleção de linhagens de sorgo granífero eficientes e responsivas à aplicação de fósforo. Pesqui Agropec Bras Brasília,49(8):613-621(b).

Sans LMA, Morais ADC, Guimarães DP (2003) Época de plantio de sorgo. Embrapa Milho e Sorgo.

Santos FC, Coelho AM, Resende AV, Miranda RA (2014) Correção do solo e adubação na cultura do sorgo. Info Agropecu, Belo Horizonte. 35(278):76-88.

Silva AG, Barros AS, Morães EB, Pires R (2009). Avaliação de cultivares de sorgo granífero na safrinha no sudoeste do Estado de Goiás. Pesqui Agropecu Tropical. 39(2):168174.

Silva KJ, Menezes CB, Tardin FD, Emygdio B, Souza VF, Carvalho GA, Silva MJ (2013). Seleção de Híbridos de Sorgo Granífero Cultivados no Verão em Três Localidades. Rev Bras Milho e Sorgo. 12(1):44-53.

Tolk JA, Howell TA, Miller FR (2013). Yield component analysis of grain sorghum grown under water stress. Field Crop Res. 145:44-51.

Vanderlip RL (1993) How a sorghum plant develops, Cooperative extension service. Manhattan, Kansas: Kansas Agricultural Experiment Station. v1203 1993.

Zotarelli L, Cardoso EG, Piccinin JL, Urquiaga S, Boddey RM, Torres E, Alves BJR (2003). Calibração do medidor de clorofila Minolta SPAD-502 para avaliação do conteúdo de nitrogênio do milho. Pesqui Agropecu Brasi 38(9):1117-1122. 